\title{
DETERMINATION OF ASEISMIC DEFORMATION ON NORTH ANATOLIAN FAULT IN ISMETPASA AND DESTEK REGIONS USING GPS DATA, TURKEY
}

\author{
Yavasoglu H. ${ }^{1}$, Alkan M.N..$^{2}$, Aladogan K..$^{2}$, Ozulu I.M. ${ }^{3}$, Ilci V. ${ }^{3}$, Sahin M. ${ }^{3}$, \\ Tombus F.E. ${ }^{3}$, Tiryakioglu $\mathrm{I}^{4}{ }^{4}$ and Kivrak S.O. ${ }^{5}$ \\ ${ }^{I}$ Istanbul Technical University, Department of Geomatics Engineering, Istanbul, Turkey, \\ yavasoglu@itu.edu.tr \\ ${ }^{2}$ Hitit University, Department of Map and Cadastre, Osmancik, Corum, Turkey, \\ nurullahalkan@hitit.edu.tr,kayhanaladogan@hitit.edu.tr \\ ${ }^{3}$ Hitit University, Department of Map and Cadastre, Corum, Turkey, imuratozulu@hitit.edu.tr, \\ veliilci@hitit.edu.tr,muratsahin@hitit.edu.tr,fengintombus@hitit.edu.tr \\ ${ }^{4}$ Afyon Kocatepe University, Department of Geomatics Engineering, Afyonkarahisar, Turkey, \\ itiryakioglu@aku.edu.tr \\ ${ }^{5}$ Hitit University, Department of Construction Technology, Corum, Turkey, \\ oguzhankivrak@hitit.edu.tr
}

\begin{abstract}
The North Anatolian Fault Zone (NAFZ) is one of the most destructive fault in the eastern Mediterranean region. After Izmit and Düzce earthquakes, the projects on monitoring the fault motion increase using instrumental tools like GPS, InSAR, LIDAR, creepmeter, etc. The eastern and central part of the NAFZ from Karliova to Vezirköprü has almost strike slip mechanism. The western part of the central NAFZ from Vezirköprü to Bolu has transpressive character. The aseismic fault deformation (creep) is also important phenomena for these two sections. The InSAR and LIDAR studies showed that the Ismetpasa and Destek regions have creep motions. For this purpose, the new project has been started to proof this phenomena with GPS data and to determine quantitatively the rate of convergence and its variation along segment of the NAF between Bolu and Çorum. The main aim of this study is determination of creep rate with geodetic measurements and combination of the data obtained from seismology, geodesy and geophysics to understand fault mechanism. Therefore, in this paper we discuss tectonic phenomena on the central part of the NAFZ and present the first results of the project.

Keywords: Deformation, Earthquake, Geodesy, Creep.
\end{abstract}

\section{Introduction}

The locked active faults can move abruptly to release the strain accumulation and produce destructive earthquakes. The earthquake mechanism along active faults can be subdivided into four periods: interseismic, preseismic, coseismic, and postseismic (Reid, 1910). This sequence is called the earthquake cycle in the literature (Reid, 1910). On the contrary, the fault can slip freely (creep) such as Hayward fault Schmidt et al. (2005), Ismetpasa and Destek segments and of the North Anatolian Fault (Ambraseys, 1970; Cakir et al., 2005; Karabacak et al., 2011). The important point 
of the creep is the threshold of the aseismic slip rate. If the creep motion has velocity equal or longer than long-term slip rate along the fault, the fault will continue to slip freely and will not produce destructive earthquake (Cakir et al., 2012). Conversely, if the aseismic slip rate is lower than the long-term slip rate of the fault, it is possible that the fault can produce the destructive earthquake (Karabacak et al., 2011). Therefore, knowledge and motoring of the aseismic fault creep and also comparing the results with long-term slip rate are critical to prevent loss of seismic hazard.

The Ismetpasa and Destek segments where lie from Bolu the west to Corum the east were ruptured by the earthquakes in 1943 (Tosya Ms=7.6), 1944 (Bolu-Gerede Ms=7.3) in the last century (Figure 1 and 2).

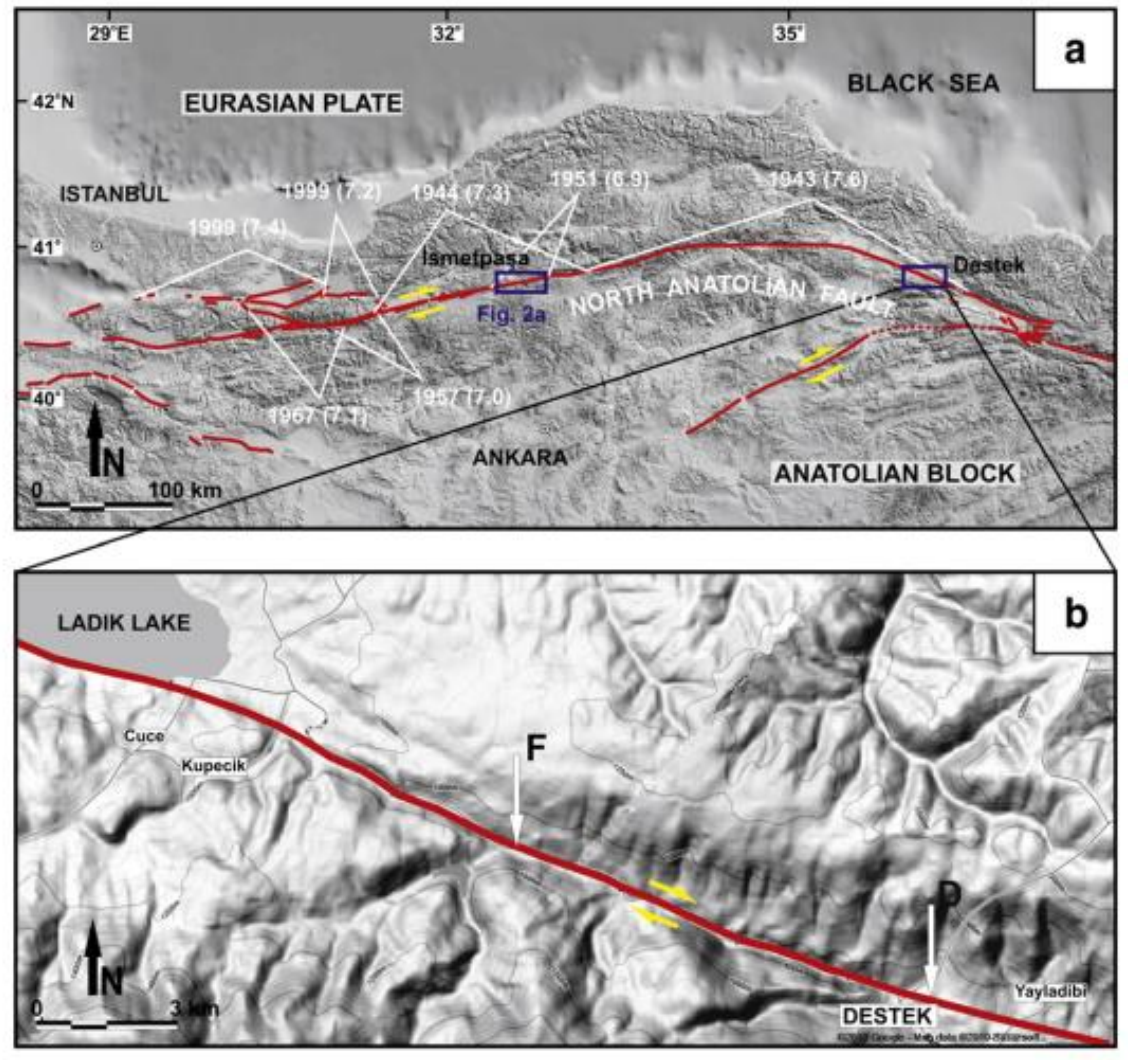

Figure 1 - (a) Simplified map of the North Anatolian Fault showing creep locations and recent major earthquakes, (b) General trend of the North Anatolian Fault around Destek segment. " $F$ " and " $D$ " indicate the locations of the surveyed areas in and near Destek (Fig. 2b) (from Karabacak et al., 2011). 

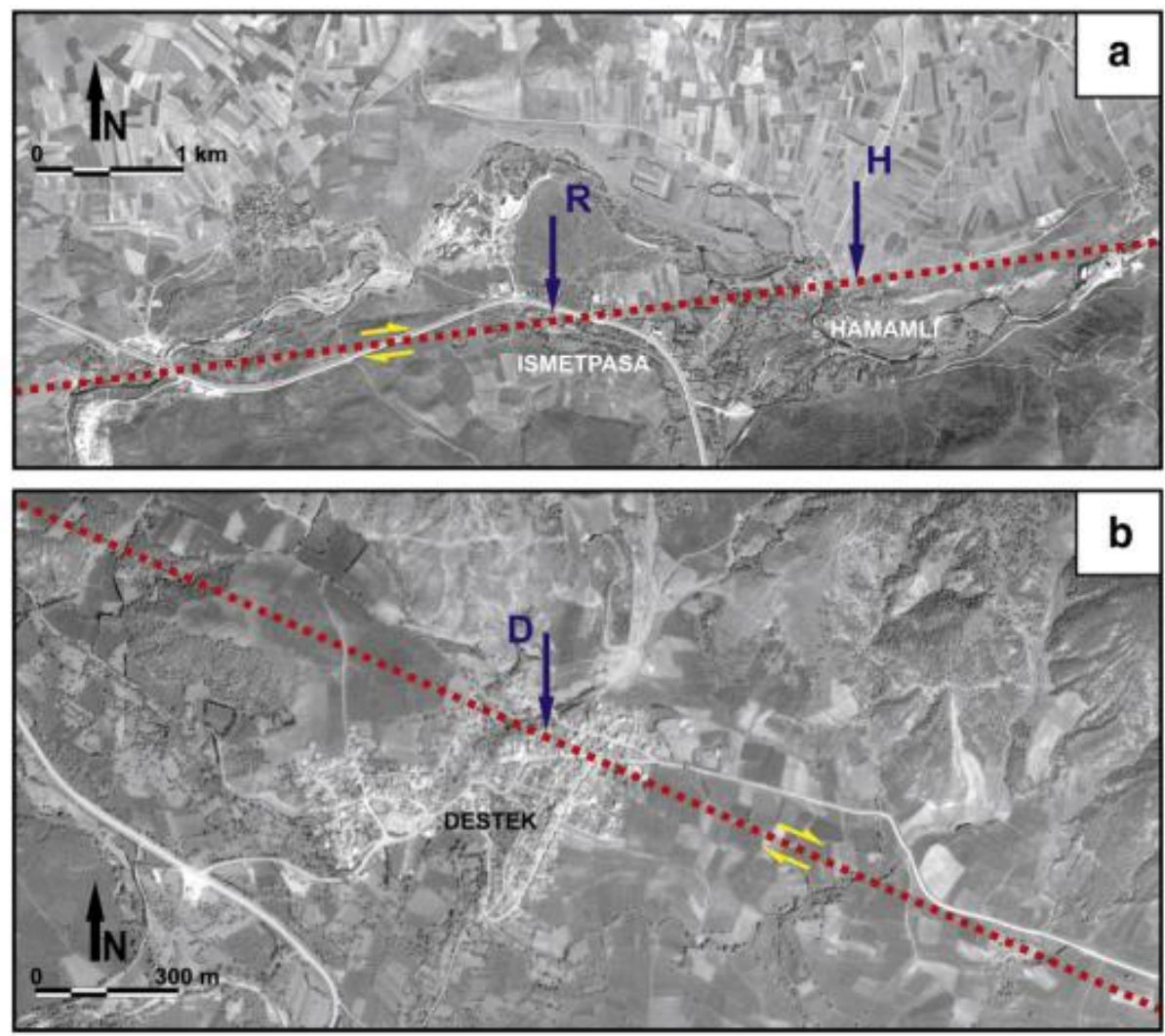

Figure 2 - (a) Detailed map of the Ismetpasa. " $R$ " is the railway station in Ismetpasa, " $H$ " is the Hamamlı Village and the dashed line is the trace of the NAF, (b) Detailed map of (D) Destek. The dashed line is the trace of the NAF (1944 surface rupture) (from Karabacak et al., 2011).

\section{Tectonic Settings}

Active faults like the NAFZ bounding or within the tectonic plates are generally locked from surface down to the bottom of the seismogenic crust, accumulating elastic strain energy over a long period of time. When the yielding stress (friction plus effective normal stress) on the fault is reached, the fault suddenly slips and produces an earthquake, releasing the accumulated energy (Cakir et al., 2012). However, some faults are known to slip aseismically at the surface down to some depths, accumulating little or no strain and thus producing less frequent or no earthquakes, respectively (Burford ve Harsh, 1980; Steinbrugge et al., 1960; Cakir et al., 2005). Therefore, it is essential to determine the presence and characteristics of such aseismic motions, known as surface creep (a phenomenon rarely observed along active strike slip faults) when determining seismic hazard of a region (Bürgmann et al., 2000b; Cakir et al., 2012).

Aseismic fault creep on the NAF was firstly reported by Ambraseys (1970) at Ismetpasa segment and calculated the rate of aseismic slip $20 \mathrm{~mm} / \mathrm{yr}$ using tape meter measurements. After Ambraseys, the first geodetic study was started by establishing triangulation and trilateration network across the fault near Ismetpasa. The geodetic measurements indicate that the rate of creep is $9.3 \pm 0.7 \mathrm{~mm} / \mathrm{yr}$ (Deniz et al., 1993) and $7.8 \pm 0.5 \mathrm{~mm} / \mathrm{yr}$ (Kutoglu and Akcin, 2006). Using InSAR technique, Cakir et al. (2005) estimated the rate $8 \pm 3 \mathrm{~mm} / \mathrm{yr}$ for the creeping on the section. The LIDAR technology was also used by Karabacak et al. (2011) to calculate the rate of 6.8-10.0 $\pm 4.0 \mathrm{~mm} / \mathrm{yr}$ and $9.1-10.1 \pm 4.0 \mathrm{~mm} / \mathrm{yr}$. Cakir et al. (2012) and Cetin et al. (2014) reported that the rate is not stable along the fault and reaches a maximum of $20 \pm 2 \mathrm{~mm} / \mathrm{yr} 20 \mathrm{~km}$ to the east from Ismetpasa (Figure 3 and 4). 


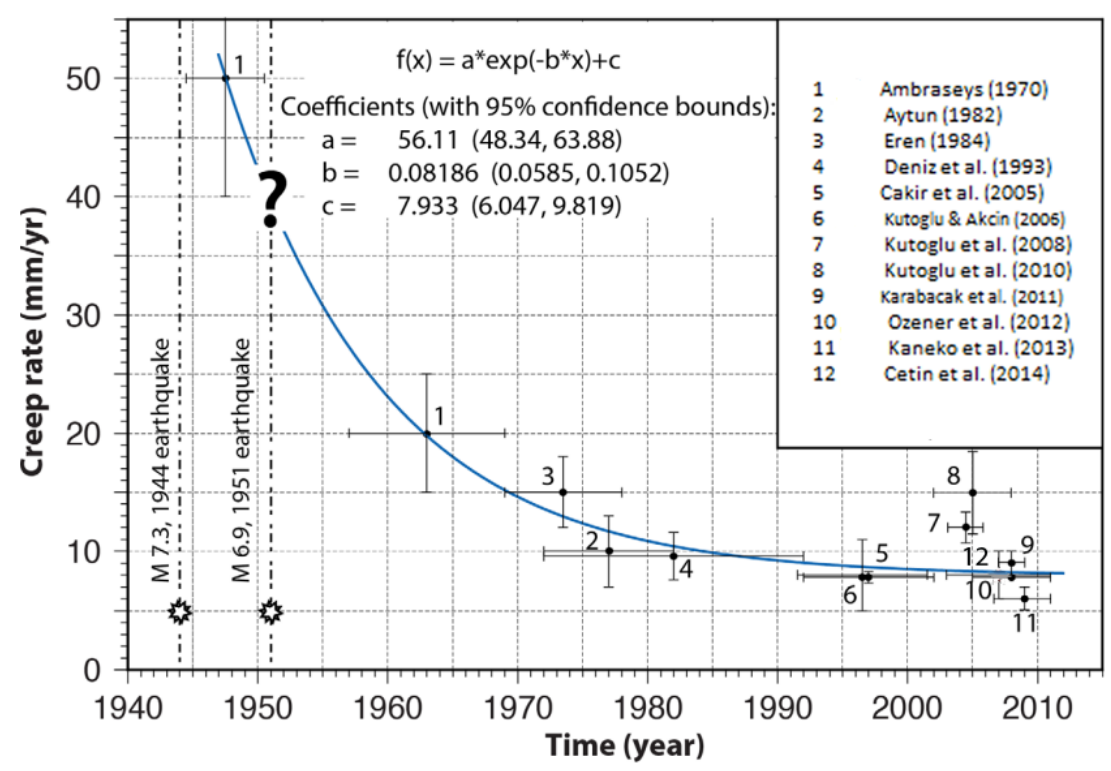

Figure 3 - Time history of surface creep at Ismetpasa as reported by various studies following the 1944 earthquake (from Cetin et al., 2014). Horizontal and vertical bars are the time window and error range of measurements, respectively. The question mark corresponds to the unknown effect of the 1951 earthquake on creep rate. Curve shows the fit of the exponential relaxation function to the change of the creep rate with time (Savage et al., 2005).

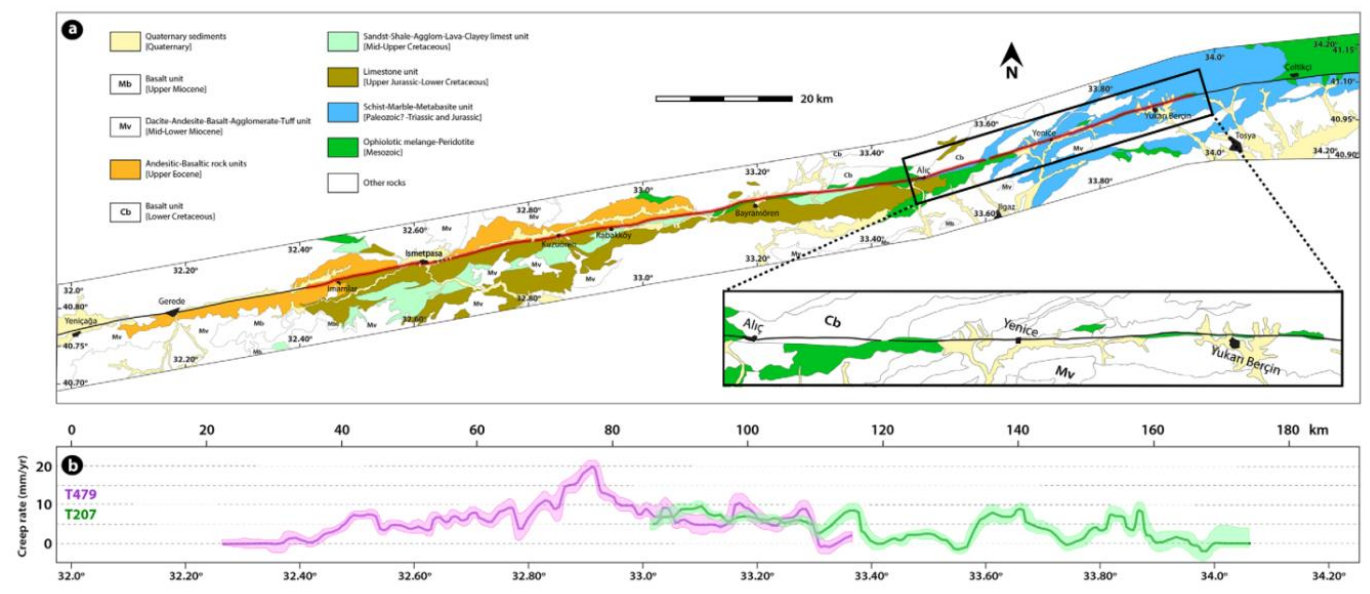

Figure 4 - (a) Geology map of the study region (Herece and Akay, 2003). Geological units presumably involved in creeping are shown in colors and the others are labeled in white with abbreviations. Black and red lines represent the active fault and the creeping segment, respectively. The eastern end of the creeping section can be clearly seen in the inset rectangle, (b) Creep rates and error ranges for two individual tracks are indicated in purple (track T479) and green colors (track T207) (from Cetin et al., 2014).

Another aseismic creep segment on the NAF was reported by Karabacak et al. (2011) in Destek village on the northeast of the Corum. This segment of the NAF was ruptured in 26 November 1943 Tosya (Ms=7.6) earthquake. LIDAR results on this part of the fault showed an aseismic slip rate of 
$6.0-7.2 \pm 4.0 \mathrm{~mm} / \mathrm{yr}$, which releases considerable amount of strain in this part of the NAF but the results of the LIDAR measurements were not verified by the another techniques, observations or studies. This can be a handicap to explain the behaviour of the fault in this segment.

The central part of the NAF in our study area, where no another aseismic surface slip section reported by previous studies. At the same time, McClusky et al. (2000), Reilinger et al. (2006), Yavasoğlu et al. (2011) and Peyret et al. (2013) indicate that the central part of the NAF in between Destek and Ismetpasa are still active and going on strain accumulation with slip rate about $20.5 \pm 1.8 \mathrm{~mm} / \mathrm{yr}$.

\section{Geodetic Measurements}

The new geodetic network with 23 stations was established to monitor the creep and non-creep segments of the NAF using GPS data (Figure 5). The geodetic GPS receivers and antennas were used to collect data. The stations were measured at least 10 hours with interval 5 seconds and 10 decree elevation mask. The most of the stations are pillars and they has force-centered system against to blunder error. The force-centered components (chain tripods) were used to fix the GNSS antenna on benchmark stations (Figure 5).

The first and second GPS campaign was carried out in August 2014 and 2015, respectively. The campaigns data both obtained from new 23 sites and 48 continuous GPS stations (IGS - The International GNSS Service and CORS-TR - Continuously Operating Reference Stations, Turkey) were evaluated by GAMIT/GLOBK software (King and Bock, 2003).

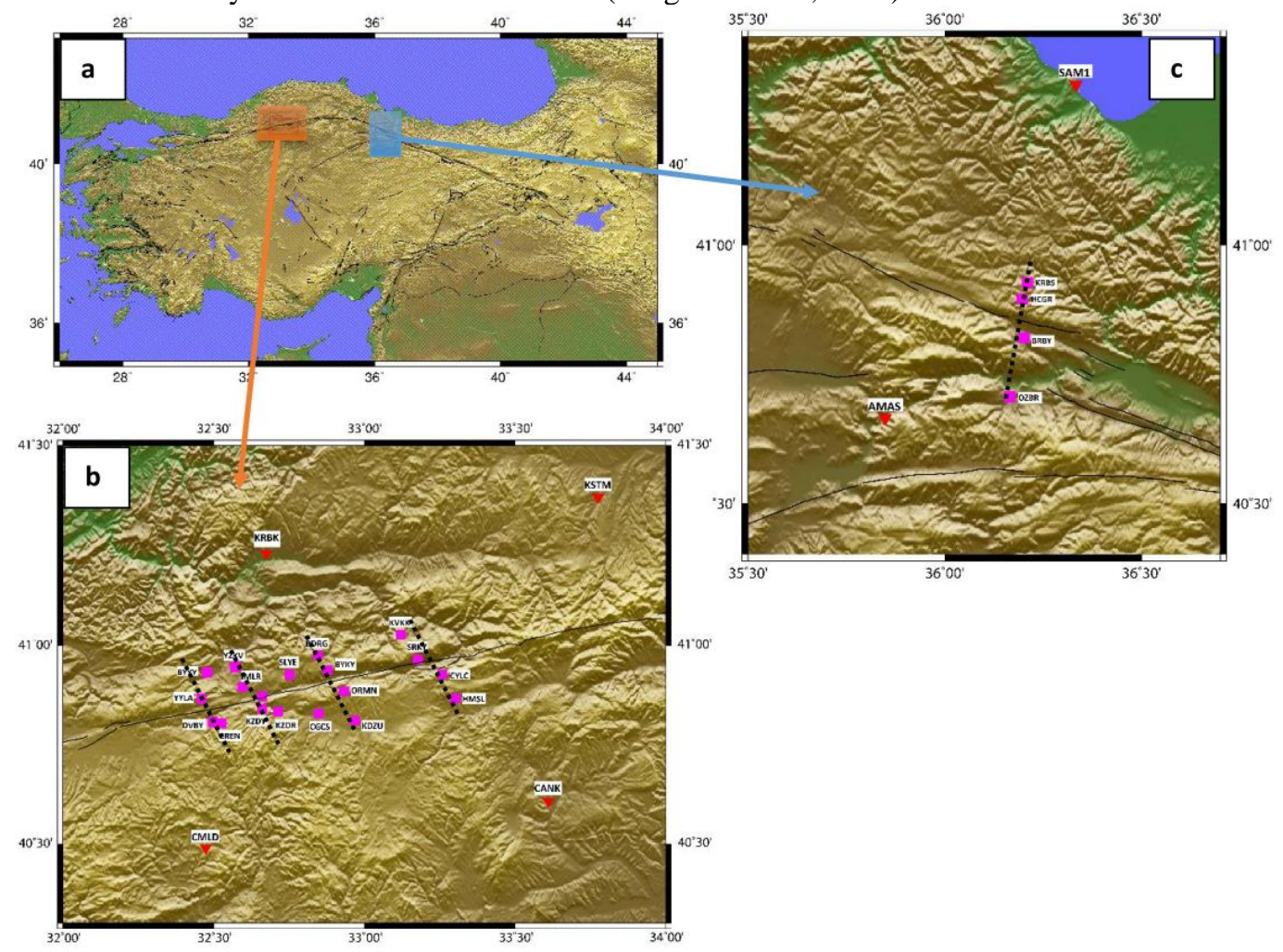

Figure 5 - (a) Active seismic fault in Turkey (Emre et al., 2013), (b) Ismetpasa segments, (c) Destek segment. Dashed lines represent the profiles, red triangles are CORS-TR stations and purple squares are these project new stations. (See in text).

Pseudo-range and phase GPS data are analysed using GAMIT software as single-day solutions. Station coordinates, satellite orbits, 13 tropospheric zenith delay parameters per site and phase 
ambiguities using double-differenced phase measurements are solved while applying loose a priori constraints to all parameters. The IGS final orbits, IERS earth orientation parameters are used, and azimuth and elevation dependent antenna phase centre models are applied.

The evaluation of data obtained from second campaign has been still continued.

\section{Conclusion}

After the evaluation of second campaign, the project will be valuable. The similarities and differences in seismological behaviour of the NAF along its creeping and non-creeping sections will be investigated for the first time in this study using GPS data. It is an important shortcoming that such an investigation has not been conducted yet even though the phenomenon of surface creep in Ismetpasa has been known for over 40 years and in Destek discovered recently. Creeping section of the San Andreas Fault at Hayward has been monitored using micro geodetic and seismic networks for many years, which have revealed important information about the rheology and temporal behaviour of the fault and its potential for producing earthquakes (Titus et al. 2006).

\section{Acknowledgments}

We would like to thank to Prof. Dr. Reha Metin Alkan the Rector of Hitit University. Financial supports of the projects are from Hitit University Fund and Istanbul Technical University Fund with numbers, MYO19001.14.001 and 38146, respectively. The figures in this paper were generated using the public domain Generic Mapping Tools (GMT) software (Wessel and Smith, 1998).

\section{References}

Ambraseys, N.N., 1970. Some characteristic features of the Anatolian fault zone, Tectonophysics, 9, 143-165.

Burford, R.O. and Harsh, P.W., 1980. Slip on the San Andreas Fault in central California from alignment array surveys, Bull. Seis. Soc. Am., 70, 1223-1261.

Bürgmann, R., Schmidt, D., Nadeau, R.M., d'Alessio, M., Fielding, E., Manaker, D., McEvilly, T. V. and Murray, M.H., 2000b, Earthquake Potential Along the Northern Hayward Fault, California, Science, 289(5482), 1178-1182.

Cakir, Z, Akoglu, AM, Belabbes, S, Ergintav, S and Meghraoui, M., 2005. Creeping along the Ismetpasa section of the North Anatolian Fault (Western Turkey): Rate and extent from InSAR, Earth and Planetary Science Letters, 238, 225-234.

Cakir, Z., Ergintav, S., Ozener, H., Dogan, U., Akoglu, A.M., Meghraoui, M. and Reilinger R., 2012. Onset of aseismic creep on major strike-slip faults, Geology, 40(12), 1115-1118.

Cetin, E, Cakir, Z, Meghraoui, M, Ergintav, S. and Akoglu, AM., 2014. Extent and distribution of aseismic slip on the Ismetpasa segment of the North Anatolian Fault (Turkey) from Persistent Scatterer InSAR, Geochemistry, Geophysics, Geosystems, 15, 2883-2894.

Deniz, R., Aksoy, A., Yalin, D., Seeger, H., Hirsch, O. and Bautsch P., 1993. Determination of crustal movement in Turkey by terrestrial geodetic methods, Journal of Geodynamics, 18, 13-22.

Emre, Ö., Duman, T.Y., Özalp, S., Elmacı, H., Olgun, Ş. and Şaroğlu, F., 2013. Active Fault Map of Turkey, Mineral Research and Exploration General Directorate, Special Issue Series-30, Ankara-Turkey.

Herece, E. and Akay, E., 2003. Atlas of North Anatolian Fault. Special Publication Series, No: 2. General Directorate of Mineral Research and Exploration, MTA, Ankara.

Karabacak, V., Altunel, E. and Cakir, Z., 2011. Monitoring aseismic creep along the North Anatolian Fault (Turkey) using ground-based LIDAR, Earth and Planetary Science Letters, 304, 6470.

King R.W. and Bock, Y., 2003. Documentation for the GAMIT GPS Analysis Software Release 10.1, Massachusetts Institute of Technology, Cambridge MA, USA. 
Kutoglu, H.S. and Akcin, H., 2006. Determination of 30-year Creep on the Ismetpasa segment of the North Anatolian Fault using an old geodetic network, Earth Planets Space, 58, 937-942.

McClusky, S., Balassanian, S., Barka, A., Demir, C., Ergintav, S., Georgiev, I., Gurkan. O., Hamburger, M., Hurst, K., Kahle, H., Kastens, K., Kekelidze, G., King, R., Kotzev, V., Lenk, O., Mahmoud, S., Mishin, A., Nadriya, M., Ouzounis, A., Paradissis, D., Peter, Y., Prilepin, M., Reilinger, R., Şanlı, I., Seeger, H., Tealeb, A., Toksöz, M.N. and Veis, G., 2000. Global Positioning System constraints on plate kinematics and dynamics in the eastern Mediterranean, Journal of Geophysical Research, 105, 5695-5719.

Peyret, M., Masson, F., Yavasoglu, H., Ergintav, S. and Reilinger, R., 2013. Present-day strain distribution across a segment of the central bend of the North Anatolian Fault Zone from a Persistent-Scatterers InSAR analysis of the ERS and Envisat archives, Geophysical Journal International, 192(3), 929-945.

Reid, H.F., 1910. The Mechanics of the Earthquake, The California Earthquake of April 18, 1906, Report of the State Investigation Commission, Carnegie Institution of Washington, 2, 16-28.

Reilinger, R., McClusky, S., Vernant, P., Lawrence, S., Ergintav, S., Çakmak, R., Özener, H., Kadirov, F., Guliev, I., Stepanyan, R., Nadariya, M., Hahubia, G., Mahmoud, S., Sakr, K., ArRajehi, A, Paradissis, D., Al-Aydrus, A., Prilepin, M., Guseva, T., Evren, E., Dmitrotsa, A., Filikov, S.V., Gomez, F., Al-Ghazzi, R. and Karam, G., 2006. GPS constraints on continental deformation in the Africa-Arabia, Eurasia continental collision zone and implications for the dynamics of plate interactions, Journal of Geophysical Research-Solid Earth, 111, B05411.

Savage, J.C., Svarc, J.L. and Yu S.B., 2005. Postseismic relaxation and transient creep, Journal of Geophysical Research, 110(B11), doi: 10.1029/2005JB003687.

Schmidt, D.A., Bürgmann, R., Nadeau, R.M. and d'Alessio, M., 2005. Distribution of aseismic sliprate on the Hayward fault inferred from seismic and geodetic data, Journal of Geophysical Research, 110, B08406, doi: 10.1029/2004JB003397.

Steinbrugge, K.V., Zacher, E.G., Tocher, D., Whitten, C.A. and Clair C.N., 1960. Creep on the San Andreas Fault, Bull. Seis. Soc. Am., 50, 396-404.

Titus, S.J., DeMets, C. and Tikoff, B., 2006. Thirty-Five-Year Creep Rates for the Creeping Segment of the San Andreas Fault and the Effects of the 2004 Parkfield Earthquake: Constraints from Alignment Arrays, Continuous Global Positioning System, and Creepmeters, Bulletin of the Seismological Society of America, 96(4B), 250-268.

Wessel, P. and Smith, W.H.F., 1998. New improved version of Generic Mapping Tools released, Eos Transactions American Geophysical Union, 79(47), 579.

Yavasoglu, H., Tari, E., Tuysuz, O., Cakir, Z. and Ergintav, S., 2011. Determining and modelling tectonic movements along the central part of the North Anatolian Fault (Turkey) using geodetic measurements, Journal of Geodynamics, 51(5) 339-343. 